\title{
Giant Cell Tumors of the Tendon Sheaths of the Big Toe: A Case Report
}

\author{
Mohamed Rida El Galiou*, Houass EY, Boufettal M, Bassir RA, Kharmaz M, Lamrani MO, Berrada MS
}

Department of Orthopedics and Traumatology, University Hospital Center of Rabat, Faculty of Medicine and Pharmacy of Rabat, University Mohammed V Souissi, Rabat, 10000, Morocco

DOI: $10.36347 /$ sjams.2020.v08i11.034

| Received: 09.11.2020 | Accepted: 21.11.2020 | Published: 23.2020

*Corresponding author: Mohamed Rida El Galiou

\section{Abstract}

Giant cell tumor of the tendon sheathsare benign tumors of strictly local malignancy with an aggressive tendency. The progressive prognosis is dominated by the risk of recurrence after surgical excision. Their management requires surgery which remains difficult and which must be well planned and correctly executed to avoid recurrence. The authors report the case of a 24 -year-old female patient with a giant cell tumor of the tendon sheaths of the big toe. The patient underwent complete tumor resection. The evolution was favorable without recurrence.

Keywords: Tumor, giant cells, synovial sheath, foot.

Copyright $(\mathcal{O} 2020$ The Author(s): This is an open-access article distributed under the terms of the Creative Commons Attribution 4.0 International License (CC BY-NC 4.0) which permits unrestricted use, distribution, and reproduction in any medium for non-commercial use provided the original author and source are credited.

\section{INTRODUCTION}

Giant Tendon Sheath Tumors or tenosynovial giant cell tumors are benign soft tissue tumors that usually occur in the limbs, most often in the hand. Their localization at the level of the foot is rare.

\section{Clinical Observation}

This is a patient, aged 24, with no particular pathological history, who consulted for swelling of the sole of the left foot, evolving for two years, spontaneous onset, gradually increasing in size, without signs of nervous vascular compression.

Examination of the left foot found on inspection an oblong plantar mass along the flexor tendon of the big toe without inflammatory signs, on palpation a tumor of $7 \mathrm{~cm} / 3 \mathrm{~cm}$, not very painful, of firm consistency, , motionless in relation to the surface plane. The mobility of the foot, vascular and nervous examination beforehand was normal. There was no inguinal or distant lymphadenopathy. The rest of the general exam was normal. Frontal x-ray of the left foot was normal. That of $3 / 4$ showed notches at the level of the first phalanx of the big toe in favor of bone erosion (fig. 1).
Ultrasound showed a tissue mass with a hypoechoic structure. The CT appearance in our patient was in favor of either a synovial tumor (benign synovioma, synovialosarcoma), or a giant cell tumor of the tendon sheaths, the possibility of a histiocytic or neurogenic tumor was not discarded. MRI revealed an aspect suggesting a tumor lesion: giant cell tumor of the flexor tendons (fig. 2).

The biopsy with pathological examination was in favor of a giant cell tumor of the tendon sheaths. The patient subsequently underwent complete tumor resection (Fig. 3.4).

Histologically, the specimen measured 9/5/1 $\mathrm{cm}$ and weighed $94 \mathrm{~g}$, it was a buff yellow neoplasm, vaguely lobulated in appearance. Microscopically (fig. $5)$, it was a tumor proliferation made up of numerous multinucleated giant cells mixed with histiocytic cells arranged in diffuse sheets. It is associated with clumps of foamy histiocytic cells within a stroma rich in blood vessels. This histologic appearance was in favor of a tenosynovial giant cell tumor.

The patient was followed regularly. The outcome was favorable without recurrence at 4 years post-treatment follow-up. 


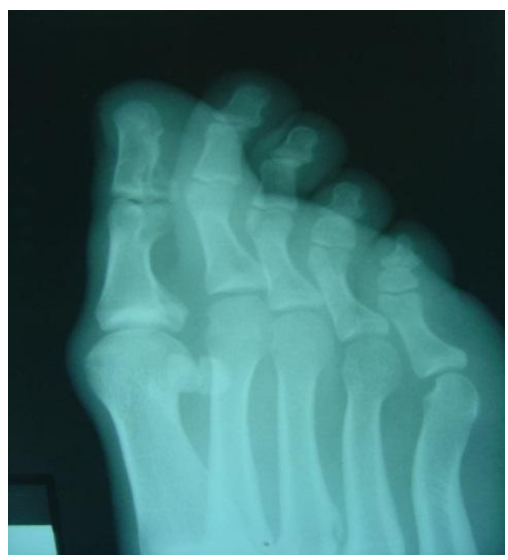

Fig-1: $x$-ray of the foot $3 / 4$ showing bony erosion of the first phalanx of the big toe in favor.
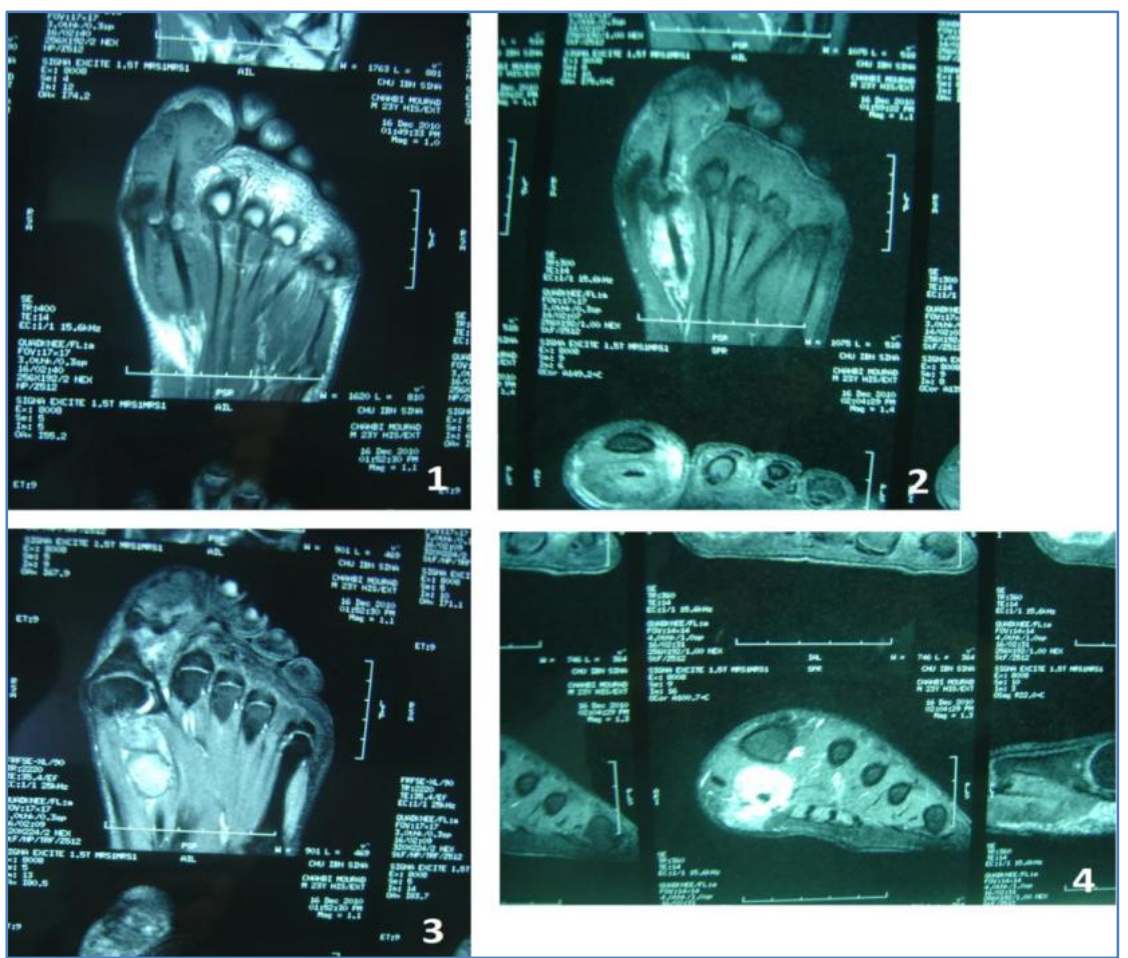

Fig-2: MRI of the left foot showing a GCTTS in T1 hypointense, T2 hypersignal

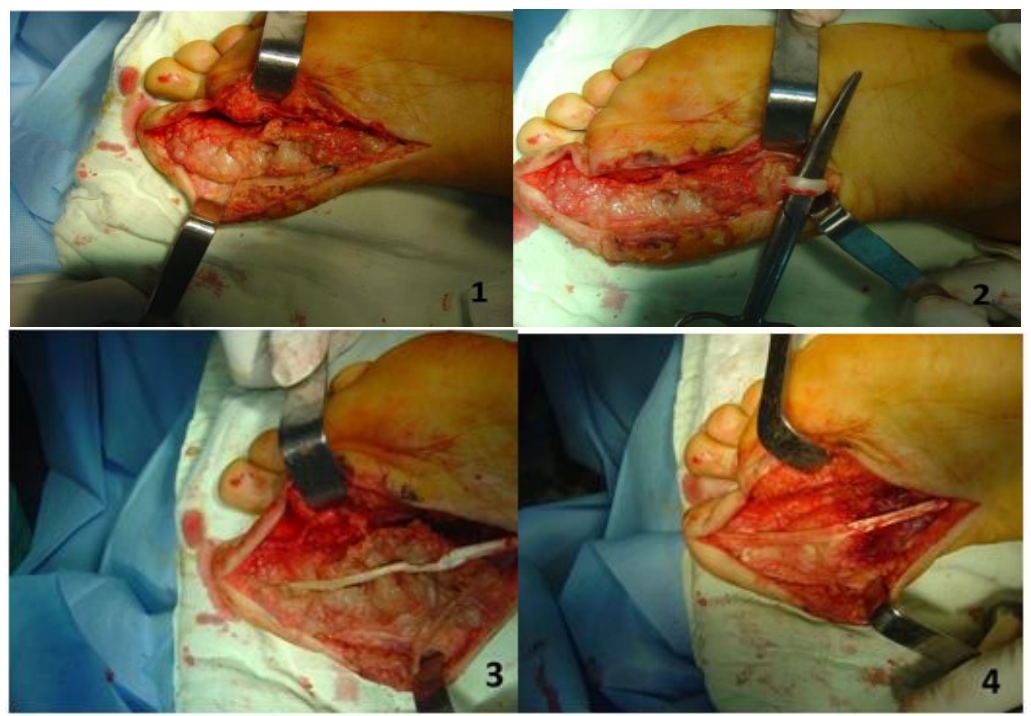

Fig-3: Intraoperative images of surgical excision of the tumor 


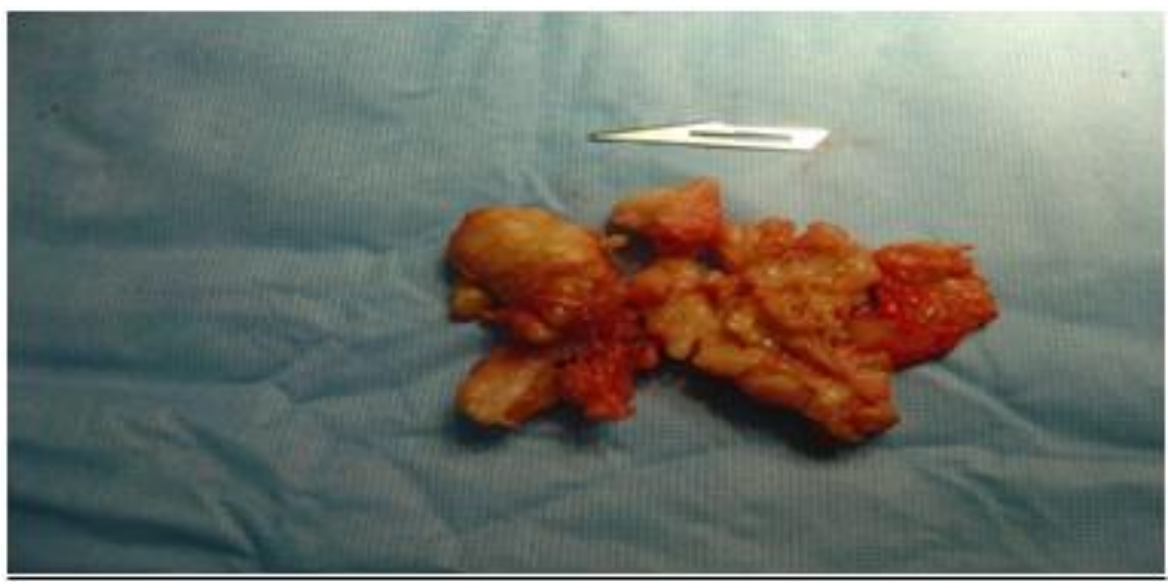

Fig-4: Macroscopic appearance of the excision piece

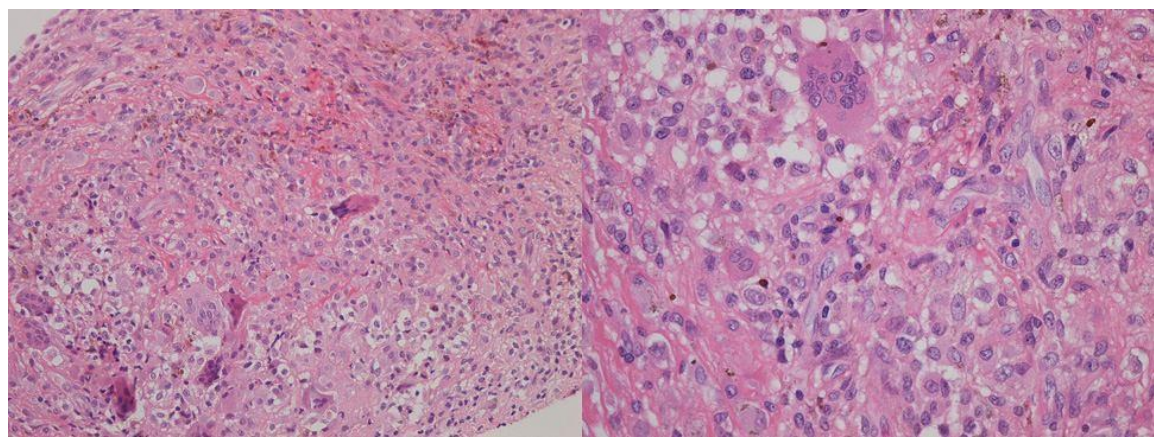

Fig-5: Microscopic appearance of GCTTS in our patient with accumulation of histiocytes, presence of multinucleated giant cells and collagen strands

\section{DisCUSSION}

Giant cell tumor of the tendon sheaths is common in the hand. It is rare in the foot, where it can be found indifferently in the articular synovial membranes, the tendon sheaths and the serous bursae [1]. GCTTSs are predominant in women ( $2 / 1$ ) and can occur at any age $[2,3]$.

Clinically, GCTTS presents as a slowly growing painless mass on the palmoplantar surfaces. The radiological signs are characterized on standard images by the association of images of the soft tissues and the bone. Bone lesions exist in $15 \%$ of cases. They combine cortical erosions and pseudo-cystic geodes simulating a malignant tumor. Often there is degenerative involvement of neighboring joints [4]. MRI shows a tumor with $\mathrm{T} 1$ iso signal and $\mathrm{T} 2$ hypersignal invading the soft parts.

Histologically, GCTTS is a proliferation of multinucleated giant cells, and histiocytes associated with foamy macrophages, and hemosiderin deposits [5].

The positive diagnosis is established by the clinic and the X-ray and is confirmed by the pathological examination. The differential diagnosis arises with synovial cyst, lipoma, fibroma, synovial chondromatosis, rheumatoid synovitis and synovialosarcoma [6].
Treatment is surgical and involves complete removal of the tumor to prevent recurrence. The tumor often presents extensions, particularly on the deep side of the tendons. When there is erosion of the cortical bone or intraosseous penetration, careful curettage of the bone is necessary. Radiotherapy is an adjuvant treatment recommended to prevent them $[2,7]$.

\section{Conclusion}

Giant cell tumor of the tendon sheaths of the foot is rare; the diagnostic times are often lengthened because of its pauci-symptomatic character, being summarized in a swelling characterized by a slow and insidious growth. Complete resection is often difficult, which would increase the rate of recurrence.

\section{REFERENCE}

1. Bonnel F. Tumeur a cellules géantes des gaines synoviales dupied. Med Chir. 1990;6:72-8.

2. Garg B, Kotwal PP. Giant cell tumour of the tendon sheath of the hand. Journal of Orthopaedic Surgery. 2011 Aug;19(2):218-20.

3. Findling J, LaScola NK, Groner TW. Giant cell tumor of the flexor hallucis longus tendon sheath: a case study. Journal of the American Podiatric Medical Association. 2011 Mar;101(2):187-9. 
4. Idrissi KK, Rafai M, Largab A, Trafeh M. Tumeur à cellules géantes des gaines des tendons extenseurs des orteils (à propos d'un cas et revue de la littérature). Médicine et Chirurgie du Pied. 2004 Jun 1;20(2):49-51.

5. M Boufettal, D.Jeddi, RABassir, MKharmaz, MO Lamrani, A EL Bardouni ,M Mahfoud, Y Bjijou , M.S Berrada. Tumeur à Cellules Géantes des Gaines Tendineuses du gros orteil à propos d'un cas et revue de la littérature. Revue Marocaine de
Chirurgie Orthopédique et Traumatologique N: 80 Année. 2019.

6. Burki S, Treves R, Jacob P. Synovite villonodulaire et synoviosarcome. Confrontations radiographique et anatomopathologique, à propos de. 1984;2:6972.

7. Williams J, Hodari A, Janevski P, Siddiqui A. Recurrence of giant cell tumors in the hand: a prospective study. The Journal of hand surgery. 2010 Mar 1;35(3):451-6. 